\title{
Uji Daya Hambat Antibakteri Kapang Endofit dari Tanaman Alang-Alang (Imperata cylindrica (L.) Beauv.) terhadap Pertumbuhan Bakteri Staphylococcus aureus dan Escherichia coli
}

\section{Antibacterial Inhibition Test of Endophytic Fungi from Alang-Alang Plants (Imperata cylindrica (L.) Beauv.) on Bacterial Growth of Staphylococcus aureus and Escherichia coli}

\author{
Makhabbah Jamilatun ${ }^{1}$, Aminah Aminah ${ }^{2}$, Shufiyani Shufiyani' \\ ${ }^{1}$ Poltekkes Kemenkes Surakarta, JL. Ksatrian, Danguran, Klaten \\ ${ }^{2}$ Poltekkes Kemenkes Banten, Jl. Dr. Sitanala, Neglasari Kota Tangerang \\ Korespondensi : makhabbah.j@gmail.com
}

\begin{abstract}
Attention to endophytic microbes has increased because it has several functions, including producing various functional compounds of secondary metabolites. Based on previous research, two endophytic fungi were isolated from the Imperata cylindrica (L.) Beauv., namely Fusarium sp. and Mucor sp. This research was conducted with the aim to determine the antibacterial activity of endophytic fungi from Imperata cylindrica (L.) Beauv.) on the growth of Staphylococcus aureus and Escherichia coli. The research began with rejuvenating and fermentation of endophytic fungi, then testing the antibacterial activity of fermentation from endophytic fungi carried out by the Kirby Bauer method. Based on the results of the study that endophytic fungi can inhibit the growth of test bacteria. Fusarium sp endophytic fungi were able to inhibit the growth of S. aureus and E.coli test bacteria with inhibition diameters of $16.2 \mathrm{~mm}$ and $16.8 \mathrm{~mm}$, respectively. While the endophytic fungi of Mucor sp were able to inhibit the growth of $S$. aureus and E. coli test bacteria with inhibition diameters of $16.2 \mathrm{~mm}$ and $15.2 \mathrm{~mm}$ in Mucor sp isolates from stems, and $21.3 \mathrm{~mm}$ and $16.3 \mathrm{~mm}$ in Mucor sp isolates originating from the root. Based on the diameter of inhibitory zones formed, the antibacterial activity of endophytic fungi of Imperata cylindrica (L.) Beauv. is included in the strong category, so that secondary metabolites of endophytic fungi from Imperata cylindrica (L.) Beauv. have the potential to be developed and can be used as a reference source in the search for new types of antibiotics.
\end{abstract}

\section{Keywords: Endophytic Fungi, Fusarium sp., Mucor sp}

\begin{abstract}
ABSTRAK
Perhatian terhadap mikroba endofit telah meningkat karena mempunyai beberapa fungsi, antara lain dapat menghasilkan berbagai senyawa fungsional metabolit sekunder. Berdasarkan penelitian sebelumnya, dua kapang endofit berhasil diisolasi dari tanaman alang-alang (Imperata cylindrica (L.) Beauv.). yaitu Fusarium sp. dan Mucor sp. Penelitian ini dilakukan dengan tujuan untuk mengetahui aktivitas antibakteri kapang endofit dari tanaman alangalang (Imperata cylindrica (L.) Beauv.) terhadap pertumbuhan bakteri Staphylococcus aureus dan Escherichia coli. Penelitian diawali dengan meremajakan dan fermentasi kapang endofit,
\end{abstract}


kemudian pengujian aktivitas antibakteri dari fermentasi kapang endofit yang dilakukan dengan metode Kirby Bauer. Berdasarkan hasil penelitian diketahui bahwa kapang endofit mampu menghambat pertumbuhan bakteri uji. Kapang endofit Fusarium sp mampu menghambat pertumbuhan bakteri uji S.aureus dan E.coli dengan diameter hambatan masingmasing sebesar $16.2 \mathrm{~mm}$ dan $16.8 \mathrm{~mm}$. Sedangkan kapang endofit Mucor sp mampu menghambat pertumbuhan bakteri uji S.aureus dan E. coli dengan diameter hambatan masing-masing sebesar $16.2 \mathrm{~mm}$ dan $15.2 \mathrm{~mm}$ pada isolat Mucor sp yang berasal dari tangkai, dan $21.3 \mathrm{~mm}$ dan $16.3 \mathrm{~mm}$ pada isolat Mucor sp yang berasal dari akar. Berdasarkan diameter zona hambat yang terbentuk maka aktivitas antibakteri kapang endofit tanaman alang-alang termasuk dalam kategori kuat, sehingga metabolit sekunder kapang endofit dari tanaman alang-alang berpotensi untuk dikembangkan serta dapat dijadikan sumber acuan dalam pencarian jenis antibiotik baru.

Kata Kunci: kapang endofit, Fusarium sp., Mucor sp.

\section{PENDAHULUAN}

Senyawa bioaktif sebagai sumber antibiotik dapat berasal dari beraneka ragam sumber daya alam, diantaranya dari tumbuhan, hewan, mikroba (Prihatiningtias, 2005). Mikroba penghasil senyawa bioaktif adalah mikroba endofit, mikroba yang berada di dalam jaringan tumbuhan hidup tanpa merugikan tumbuhan inangnya (Strobel and Daisy, 2003).

Mikroba endofit dapat ditemukan di dalam jaringan tumbuhan seperti biji, daun, bunga, buah, ranting, batang dan akar. Menurut Rodriguez et al. (2008), hubungan antara mikroba endofit dan tanaman inang merupakan bentuk simbiosis mutualisme, yaitu sebuah bentuk hubungan yang saling menguntungkan. Mikroba endofit memperoleh nutrisi dari tubuh tanaman inang, sebaliknya tanaman inang memperoleh proteksi terhadap patogen dari senyawa yang dihasilkan mikroba endofit (Bacon, 2000).

Menurut Onifade (2007), mikroba endofit mampu menghasilkan senyawa bioaktif yang sama dengan tanaman inangnya. Hal ini terjadi karena adanya kemungkinan transfer genetik antara tanaman inang dan mikroba endofit, sehingga zat-zat yang bermanfaat di tanaman juga dapat dihasilkan oleh mikroba endofitnya (Syarmalina et al., 2007). Jika mikroba endofit diisolasi dari tanaman obat maka senyawa metabolit sekunder yang dihasilkan sama seperti yang terkandung di tanaman inangnya. Hal ini merupakan peluang untuk mendapatkan sumber bahan obat yang alami, murah dan ramah lingkungan (Radji, 2005).

Mikroba endofit mempunyai arti ekonomis karena mikroorganisme merupakan organisme yang mudah 
ditumbuhkan, memiliki siklus hidup yang pendek dan dapat menghasilkan senyawa bioaktif dalam waktu cepat (Agusta, 2009). Sehingga mikroorganisme dalam hal ini endofit perlu digali dan dikembangkan, mengingat kebutuhan bahan baku obat yang semakin meningkat baik jumlah maupun macamnya.

Mikroba endofit di dalam bagian tanaman dapat terdiri dari berbagai macam, salah satunya yang paling banyak diisolasi yaitu kapang endofit (Strobel and Daisy, 2003; Rahmawaty, 2012). Kapang endofit merupakan golongan mikroba endofit yang paling banyak ditemukan dan terdapat dalam jumlah yang besar di alam ini. Besarnya perkiraan tersebut disebabkan satu spesies tumbuhan dapat dikolonisasi oleh satu atau beberapa kapang endofit (Dhanalakshmi et al. 2013).

Perhatian terhadap mikroba endofit telah meningkat dalam beberapa tahun terakhir karena mempunyai beberapa fungsi, antara lain dapat menghasilkan berbagai senyawa fungsional metabolit sekunder berupa senyawa antikanker, antivirus, antibakteri, antikapang dan sebagainya (Strobel and Daisy, 2003).

Berdasarkan penelitian yang telah dilakukan Jamilatun (2018), kapang endofit berhasil diisolasi dari alang-alang (Imperata cylindrica (L.) Beauv.), akan tetapi kemampuannya dalam menghasilkan metabolit sekunder sebagai senyawa bioaktif belum diketahui. Oleh karena itu pada penelitian ini akan dilakukan Uji Daya Hambat Antibakteri Kapang Endofit dari Tanaman Alang-Alang (Imperata cylindrica (L.) Beauv.) terhadap pertumbuhan bakteri Staphylococcus aureus dan Escherichia coli.

\section{METODE}

Desain yang digunakan pada penelitian ini adalah deskriptif dengan uji laboratorium. Tim pada penelitian ini terdiri dari satu ketua dan dua anggota. Penelitian ini dilaksanakan pada bulan Maret - Agustus 2019. Sampel diambil dari Tanaman AlangAlang (Imperata cylindrica (L.) Beauv.) yang Tumbuh di Neglasari Kota Tangerang. Uji antibakteri kapang endofit dari tanaman alang-alang (Imperata cylindrica (L.) Beauv.) terhadap pertumbuhan bakteri Staphylococcus aureus dan Escherichia coli dilakukan di Laboratorium Mikrobiologi Jurusan Jurusan Teknologi Laboratorium Medis Poltekkes Kemenkes Banten.

Uji aktivitas antibakteri kapang endofit dari tanaman alang-alang (Imperata cylindrica (L.) Beauv.) terhadap pertumbuhan bakteri Staphylococcus aureus dan Escherichia coli dilakukan dengan metode difusi cakram (Kirby Bauer). Bahan-bahan yang digunakan 
meliputi tanaman kapang endofit Fusarium sp dan Mucor sp., isolat murni Eschericia coli dan Staphylococcus aureus, media Potato Dextrose Agar (PDA), media Potato Dextrose Broth (PDB), media Muller Hinton Agar (MHA), media Nutrien Agar (NA), paper disk/kertas cakram, kloramfenikol, $\mathrm{NaCl}$ fisiologis steril, spiritus, alkohol 70\%, aquades steril, tissue. Peralatan yang digunakan antara lain: lampu spirtus, inkubator, autoclave, ose, oven, hot plate, magnetic stirrer, lemari pendingin, laminar air flow, incubator shaker, sentrifuge, pipet ukur, batang pengaduk, botol semprot, gelas kimia, erlenmeyer, neraca analitik, mikroskop, cawan petri, spreader, gelas ukur, rak tabung reaksi, kaca objek dan kaca penutup, lap tangan, pinset, botol alkohol, pisau, plastik pembungkus, aluminium foil, kapas steril, kertas kopi, kain kassa, tabung reaksi, pipet mikropipet dan tip, penggaris.

\section{Penyiapan Sampel Kapang Endofit}

Kapang endofit yang digunakan merupakan hasil isolasi dari tanaman alangalang (Imperata cylindrica (L.) Beauv.). Dua kapang endofit yang dipakai pada penelitian ini adalah Fusarium sp dan Mucor sp. Penelitian diawali dengan meremajakan kapang endofit. Peremajaan isolat kapang endofit dilakukan dengan menumbuhkan kembali isolat-isolat kapang endofit yang telah murni ke dalam media Potato Dextrose Agar (PDA) dan diinkubasi selama 5 hari.

\section{Peremajaan Bakteri Uji}

Bakteri uji Eschericia coli dan Staphylococcus aureus diinokulasikan ke dalam media Nutrien Agar (NA), selanjutnya diinkubasi pada suhu $37^{\circ} \mathrm{C}$ selama 24 jam.

\section{Produksi metabolit sekunder}

Isolat kapang endofit yang telah murni ditumbuhkan dalam media Potato Dextrose Agar (PDA) selama 5 hari hingga bersporulasi. Dengan menggunakan ose isolat yang telah murni tersebut diambil 5 potong dengan ukuran $1 \times 1 \mathrm{~cm}$ dan dimasukkan ke dalam erlenmeyer yang berisi $40 \mathrm{ml}$ Potato dextrose broth (PDB). Erlenmeyer diinkubasi dalam inkubator shaker pada suhu ruang $\left(27-30^{\circ} \mathrm{C}\right)$, pengocokan dengan kecepatan $120 \mathrm{rpm}$ selama 14 hari, kemudian diambil $20 \mathrm{ml}$ dari media starter dan dimasukkan ke dalam erlenmeyer yang berisi $200 \mathrm{ml}$ media PDB. Setelah itu dilakukan fermentasi, pengocokan dengan kecepatan $120 \mathrm{rpm}$ pada suhu ruang $\left(27-30^{\circ} \mathrm{C}\right)$. Pada hari ke9 hasil fermentasi diambil dan disentrifugasi dengan kecepatan 3000 rpm selama 10 menit pada suhu ruang. Supernatan dipisahkan dari biomassanya. Supernatan yang diperoleh kemudian 
digunakan untuk merendam paper disk/kertas cakram yang akan dipakai untuk pengujian antibakteri.

\section{Persiapan mikroba uji}

Suspensi bakteri uji dibuat dengan mengambil koloni yang tumbuh pada media dengan menggunakan ose kemudian dimasukkan ke dalam masing-masing tabung yang berisi $5 \mathrm{ml}$ aquadest steril. Suspensi diencerkan sehingga diperoleh suspensi bakteri uji dengan konsentrasi yang telah distandarisasi sesuai dengan standar Mc.Farland 0.5 (setara dengan $1.5 \mathrm{x}$ $10^{8}$ ), untuk pengujian anti bakteri.

\section{Uji Antibakteri}

Uji aktivitas antibakteri dilakukan dengan metode difusi agar menggunakan metode uji Kirby-Bauer menggunakan kertas cakram. Mikroba uji yang digunakan adalah Staphylococcus aureus dan Escherichia coli. Sebagai kontrol positif untuk bakteri Gram-positif dan Gramnegatif digunakan antibiotik kloramfenikol, dan aquades digunakan sebagai kontrol negatif. Secara aseptik, kertas cakram yang sudah disterilkan dicelupkan ke dalam larutan uji yang mengandung isolat endofit dan didiamkan selama 30 menit atau dengan konsentrasi larutan uji $50 \mu \mathrm{L} /$ disc diteteskan pada kertas cakram steril (diameter $6 \mathrm{~mm}$ ) dan dibiarkan mengering. Paper disk yang telah ditetesi/direndam dalam larutan uji diletakkan pada permukaan medium Muller Hinton Agar (MHA) yang telah berisi bakteri uji dalam hal ini Staphylococcus aureus dan Escherichia coli, selanjutnya diinkubasi selama $1 \times 24$ jam pada suhu $37{ }^{0} \mathrm{C}$. Apabila di sekitar kertas cakram terbentuk wilayah jernih/daerah bening maka hal ini menunjukkan indikasi kepekaan bakteri terhadap bahan/senyawa antimikroba yang terkandung di dalam kapang endofit. Daerah bening tersebut selanjutnya diukur diameternya menggunakan jangka sorong/penggaris. Selanjutnya ditentukan kategori zona hambat yang terbentuk. Menurut Davis Stout, kekuatan antibakteri dikategorikan, sangat kuat jika daerah hambatan $20 \mathrm{~mm}$ atau lebih, kuat jika daerah hambatan $10 \mathrm{~mm}-20 \mathrm{~mm}$, sedang jika daerah hambatan 5-10 $\mathrm{mm}$ dan lemah jika daerah hambatan $5 \mathrm{~mm}$ atau kurang (Setyaningsih, 2008).

\section{Analisis Data}

Data yang diperoleh dari aktivitas kapang antibakteri kapang endofit Fusarium sp. dan Mucor sp. terhadap bakteri Staphylococcus aureus dan Escherichia coli, dianalisis statistik menggunakan Analisis Variansi (Anava) untuk mengetahui ada tidaknya pengaruh perlakuan. 


\section{HASIL DAN PEMBAHASAN}

Tabel 1. Hasil Uji Daya Hambat Kapang Endofit dari Tanaman Alang-Alang (Imperata cylindrica (L.) Beauv.) terhadap Staphylococcus aureus dan Eschericia coli

\begin{tabular}{|c|c|c|c|c|c|c|}
\hline \multirow[t]{2}{*}{ Mikroba Uji } & \multirow[t]{2}{*}{ Ulangan } & \multicolumn{5}{|c|}{ Diameter Zona Hambat (mm) } \\
\hline & & $\begin{array}{c}\text { Fusarium } \\
\text { sp }\end{array}$ & $\begin{array}{c}\text { Mucor } \\
\text { sp. A }\end{array}$ & $\begin{array}{c}\text { Mucor sp. } \\
\text { B }\end{array}$ & $\mathrm{K}(+)$ & $\begin{array}{c}\mathrm{K}(- \\
)\end{array}$ \\
\hline Staphylococcu & 1 & 16 & 16 & 22 & & \\
\hline \multirow[t]{3}{*}{$s$ aureus } & 2 & 16 & 17 & 22 & 21 & 0 \\
\hline & 3 & 16.5 & 15.5 & 20 & & \\
\hline & Rata2 & 16.2 & 16.2 & 21.3 & & \\
\hline \multirow[t]{4}{*}{ Eschericia coli } & 1 & 15 & 15 & 15 & & \\
\hline & 2 & 17 & 15 & 16 & 21 & 0 \\
\hline & 3 & 18.5 & 15.5 & 18 & & \\
\hline & Rata2 & 16.8 & 15.2 & 16.3 & & \\
\hline
\end{tabular}

Ket: Fusarium sp. (Isolat kapang endofit dari bunga), Mucor sp. A (Isolat kapang endofit dari tangkai), Mucor sp. B (Isolat kapang endofit dari akar)

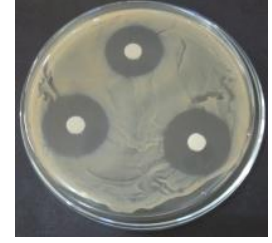

Fusarium $s p$

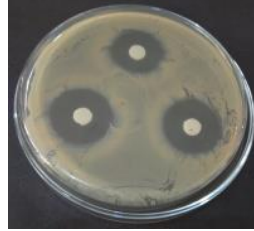

Mucor sp A

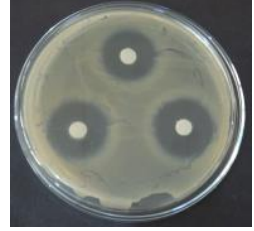

Mucor sp B

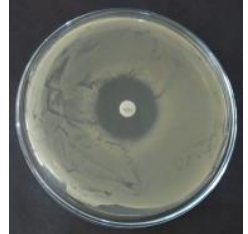

Kontrol +

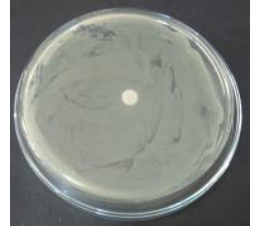

Kontrol -

Gambar 1. Daya Hambat Antibakteri Kapang Endofit dari Tanaman Alang-Alang (Imperata cylindrica (L.) Beauv.) terhadap Pertumbuhan Bakteri Staphylococcus aureus.

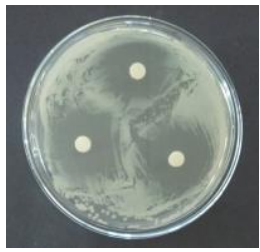

Fusarium sp

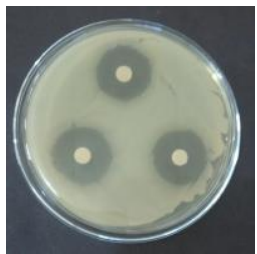

Mucor sp A

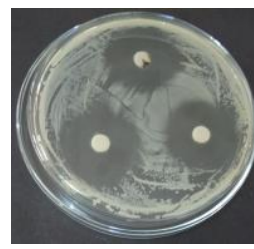

Mucor sp B

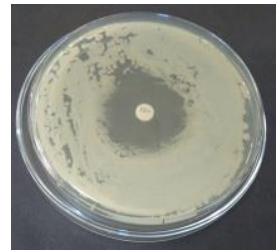

Kontrol +

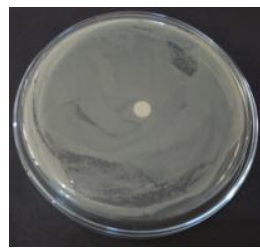

Kontrol -

Gambar 2. Daya Hambat Antibakteri Kapang Endofit dari Tanaman Alang-Alang (Imperata cylindrica (L.) Beauv.) terhadap Pertumbuhan Bakteri Escherichia coli

Berdasarkan pengujian aktivitas antibakteri diketahui bahwa isolat fungi endofit mampu menghambat pertumbuhan bakteri uji. Kapang endofit Fusarium sp mampu menghambat pertumbuhan bakteri uji S.aureus dan E.coli dengan diameter hambatan masing-masing sebesar $16.2 \mathrm{~mm}$ dan $16.8 \mathrm{~mm}$. Sedangkan Kapang endofit Mucor sp mampu menghambat pertumbuhan bakteri uji S.aureus dan $E$. coli dengan diameter hambatan masingmasing sebesar $16.2 \mathrm{~mm}$ dan $15.2 \mathrm{~mm}$ pada 
isolat Mucor sp yang berasal dari tangkai, dan $21.3 \mathrm{~mm}$ dan $16.3 \mathrm{~mm}$ pada isolat Mucor sp yang berasal dari akar. Berdasarkan analisis data Anova, aktivitas kapang endofit memiliki perbedaan pada bakteri S.aureus, dan tidak terdapat perbedaan pada bakteri E.coli. Kapang endofit Mucor sp dari akar memberikan pengaruh yang berbeda terhadap pertumbuhan S.aureus sedangkan kapang endofit Fusarium sp dan Mucor sp dari tangkai tidak memberikan pengaruh yang berbeda terhadap pertumbuhan S.aureus maupun E.coli. Pada kontrol positif yaitu kloramfenikol juga terdapat aktivitas dengan zona hambar $21 \mathrm{~mm}$ baik pada bakteri S.aureus dan E. coli sedangkan pada kontrol negatif tidak terdapat aktivitas apapun.

Daya hambat bakteri adalah kemampuan suatu senyawa aktif untuk menghambat pertumbuhan bakteri, yang diketahui dengan adanya zona hambatan pertumbuhan bakteri di sekeliling cakram, sehingga bakteri yang diujikan bersifat sensitif terhadap senyawa aktif tersebut (Waluyo, 2010). Berdasarkan diameter zona hambat yang terbentuk maka aktivitas antibakteri dari kapang endofit tanaman alang-alang ini termasuk dalam kategori kuat dan memiliki kemampuan penghambatan yang tinggi terhadap pertumbuhan bakteri. Hal ini menunjukkan bahwa isolat fungi endofit memiliki aktivitas antibakteri spektrum luas karena mampu menghambat bakteri gram positif $S$. aureus dan bakteri gram negatif yaitu $E$. coli. Hal ini sesuai dengan Davis Stout, bahwa kekuatan antibakteri dapat ditentukan dalam kategori kuat jika daerah hambatan berkisar $10 \mathrm{~mm}-20 \mathrm{~mm}$ (Setyaningsih, 2008).

Kemampuan isolat fungi endofit menghambat pertumbuhan bakteri uji disebabkan karena isolat kapang endofit mengandung senyawa aktif yang mampu menghambat pertumbuhan bakteri. Aktifitas penghambatan bakteri yang dimiliki oleh kapang endofit dipengaruhi oleh kandungan senyawa metabolit sekunder di dalamnya (Rodriguez, et.al., 2008). Pengujian aktivitas antibakteri dari kapang endofit tanaman alang-alang dilakukan pada isolat kapang yang telah difermentasi dengan tujuan untuk menghasilkan sel kapang endofit dalam jumlah banyak sehingga mengoptimalkan senyawa metabolit yang dihasilkan. Proses fermentasi selama 14 hari dikarenakan hari ke-14 merupakan waktu fermentasi yang menghasilkan pertumbuhan kapang dan produksi metabolit maksimum (Atika, 2007; Mabrouk et al., 2008). Selain itu, mikroba endofit mampu menghasilkan 
senyawa yang mirip dengan inangnya yang diduga sebagai hasil transfer genetik dari inang (Tan dan Zao, 2001). Sebagaimana diketahui tanaman alang-alang adalah salah satu jenis tanaman obat yang memiliki kandungan metabolit sekunder, pada penelitian Seniwaty dkk (2009), menyebutkan bahwa tanaman alang-alang mengandung alkaloid sebesar $1,07 \%$ dan flavonoid sebesar 4,8\%. Ditambahkan oleh Kurniati dkk (2018) dan Ramadhiani dkk. (2018), menyebutkan bahwa metabolit sekunder yang terkandung pada alang-alang meliputi senyawa alkaloid, triterpenoid dan fenolik.

Dari hasil pengukuran diameter zona hambatan terlihat bahwa kemampuan isolat kapang endofit Fusarium sp. lebih besar dalam menghambat pertumbuhan $E$ coli dibandingkan dengan S.aureus. Sedangkan kapang endofit Mucor sp. lebih menghambat pertumbuhan S.aureus dibandingkan dengan E.coli. Hal ini disebabkan karena komponen dari dinding sel kedua bakteri uji berbeda. E.coli merupakan bakteri gram negatif, dinding selnya mengandung sedikit peptidoglikan dan banyak mengandung lipid. Sedangkan S.aureus merupakan bakteri gram positif dengan kandungan peptidoglikan yang tebal dan lipid yang rendah (Jawetz et al. 2014). Selain struktur bakteri, menurut Munifatul
(2007), perbedaan diameter zona hambat juga disebabkan oleh beberapa faktor diantaranya kecepatan difusi, ukuran molekul dan stabilitas bahan antibakteri, sifat media yang digunakan, jumlah organisme yang diinokulasi, kecepatan tumbuh bakteri, konsentrasi bahan kimia serta kondisi pada saat inkubasi. Ditambahkan oleh Pelczar dan Chan (2008), faktor terhambatnya pertumbuhan bakteri tidak hanya dikarenakan adanya kerusakan dinding sel oleh senyawa antibakteri, tetapi dapat terjadi karena adanya perubahan molekul protein atau asam nukleat, penghambatan kerja enzim yang akan mengakibatkan terganggunya metabolisme atau matinya sel serta penghambatan sintesis asam nukleat dan protein sehingga menyebabkan kerusakan total pada bakteri.

Hasil uji daya hambat antibakteri kapang endofit dari tanaman alang-alang (Imperata cylindrica (L.) Beauv.) terhadap pertumbuhan bakteri S.aureus dan E.coli ini menunjukkan bahwa diantara semua isolat kapang endofit yang diuji bersifat sensitif terhadap bakteri S.aureus dan E.coli. Hasil ini sesuai dengan beberapa penelitian sebelumnya. Penelitian yang dilakukan Sukriani dkk (2018), menunjukkan bahwa fungi endofit dari daun kelor memiliki aktivitas menghambat bakteri bakteri 
S.aureus $(16,85 \mathrm{~mm})$ dan E.coli $(17,94$ $\mathrm{mm})$. Penelitian yang dilakukan Andriani (2015), menunjukkan bahwa fungi endofit dari Caulerpa racemosa mampu menghambat pertumbuhan bakteri S.aureus $(18,35 \mathrm{~mm})$ dan E.coli $(18,5 \mathrm{~mm})$. Penelitian Priya et al (2018), menunjukkan bahwa kapang endofit Fusarium moniliforme mampu mengambat bakteri S.aureus $(17 \mathrm{~mm})$ dan E.coli $(20 \mathrm{~mm})$. Penelitian Gayathri et al. (2018), menunjukkan bahwa kapang endofit Fusarium sp. dari tanaman Phyllanthus reticulatus Poir efektif menghambat Escherichia coli dengan zona hambat sebesar $10 \mathrm{~mm}$. Hasil penelitian Manar et al (2018) menunjukkan bahwa kapang endofit Mucor racemosus, memiliki aktivitas antibakteri degan zona hambat $13 \mathrm{~mm}$ terhadap S. aureus. Penelitian Rosalina dkk (2018), menunjukkan bahwa kapang endofit dari mangga podang memiliki sensitifitas terhadap bakteri S.aureus dan E.coli dengan zona hambat yang dihasilkan juga lebih baik dibandingkan antibiotik ciprofloxacin dan kloramfenikol. Kapang endofit Fusarium sp dari tanaman Cinnamomum mercadoi menghambat pertumbuhan bakteri gram positif S.aureus dan gram negatif E.coli (Marcellano et al., 2017).

Hasil penelitian ini menunjukkan bahwa metabolit sekunder kapang endofit dari tanaman alang-alang merupakan antimikroba yang peka dan berpotensi untuk dikembangkan serta dapat dijadikan sumber acuan dalam pencarian jenis antibiotik baru. Oleh karena itu perlu dilakukan penelitian lebih lanjut, untuk mempurifikasi dan mengetahui jenis senyawa aktif serta konsentrasi metabolit sekunder yang terkandung dalam isolat kapang endofit dari tanaman alang-alang dan selanjutnya dapat diproduksi dalam skala besar.

\section{SIMPULAN}

Kapang endofit dari tanaman alang-alang (Imperata cylindrica (L.) Beauv.) mempunyai aktivitas antibakteri terhadap pertumbuhan bakteri Staphylococcus aureus dan bakteri Escherichia coli. Kapang endofit Fusarium sp mampu menghambat pertumbuhan bakteri uji S.aureus dan E.coli dengan diameter hambatan masing-masing sebesar $16.2 \mathrm{~mm}$ dan $16.8 \mathrm{~mm}$. Sedangkan kapang endofit Mucor sp mampu menghambat pertumbuhan bakteri uji S.aureus dan $E$. coli dengan diameter hambatan masingmasing sebesar $16.2 \mathrm{~mm}$ dan $15.2 \mathrm{~mm}$ pada isolat Mucor sp yang berasal dari tangkai, dan $21.3 \mathrm{~mm}$ dan $16.3 \mathrm{~mm}$ pada isolat Mucor sp yang berasal dari akar. Dari hasil ini disarankan perlunya dilakukan 
penelitian untuk mengeksplorasi spesiesspesies kapang endofit dan senyawa bioaktif yang dihasilkan dari berbagai jenis tanaman yang dapat dijadikan sumber acuan dalam pencarian jenis antibiotik baru.

\section{DAFTAR PUSTAKA}

Adekunle OA, Adesola AA, Akintunde and Patrick OO., 2010. Antibiotics resistance and susceptibility pattern of a strain of Staphylococus aureus associated with acne. International Journal of Medicine and Medical Sciences Vol. 2(9), pp. 277-280

Agusta, Andria. 2009. Biologi dan Kimia Kapang Endofit. ITB. Bandung.

Andriani. 2015. Aktivitas Antibakterial Fungi Endofit Caulerpa racemosa Terhadap Bakteri Escherichia coli dan Staphylococcus aureus. Prosiding Seminar Nasional Mikrobiologi Kesehatan dan Lingkungan. Makassar, 29 Januari 2015.

Atika, Dian. 2007. Uji Aktivitas Antimikroba Hasil Fermentasi Kapang Endofit yang diisolasi dari Akar, Batang, Daun Tanaman Garcinia fructiosa Lauterb dan Garcinia lasteriflora Blume serta Akar dan Daun Tanaman Garcinia cowa Roxb. Skripsi. Sarjana Farmasi. Depok: FMIPA UI.

Bacon,C.W., Microbial Endophytes. 2000 Marcell Dekker, New York, 3 - 20.

Dhanalakshmi R, Umamaheswari S, Sugandhi P, Prasanth DA. 2013. Biodiversity of the endphytic kapang isolated from Moringa oleifera of Yercaud Hills. Intl J Pharm Stud Res 4 (3): 1064-1068.

Gayathri Pai, Chandra M. 2018. Antimicrobial Activity of Endophytic Fungi Isolated from Ethnomedicinal Plant Phyllanthus reticulatus Poir. International Journal of Engineering Science Invention (IJESI). www.ijesi.org \|Volume 7 Issue $1 \|$ January 2018 || PP. 40-46.

Jamilatun, M. dan Shufiyani. 2019. Isolasi dan Identifikasi Kapang Endofit dari Tanaman Alang-Alang (Imperata cylindrica) (L.) BEAUV.). Jurnal Biomedika 12 (1): 1-8, Maret 2019.

Jawetz, Melnick, dan Adelberg. 2014. Mikrobiologi Kedokteran. Edisi 25. EGC. Jakarta.

Kurniati, T, Daniel, Sudrajat. 2018. Uji Toksisitas Dan Sifat Alelopati Ekstrak Alang-Alang (Imperata cylindrica) terhadap Perkecambahan Biji Padi (Oryza sativa). Jurnal Atomik, 2018, 03 (1) hal 54-60.

Mabrouk et al. 2008. Production of Some Biologically Active Secondary Metabolites from Marine Derived Fungus Varicosporina ramulosa. Malaysian Journal of Microbiology. Vol 4(1):14-24.

Manar A. Basheer, Amal A. Mekawy, Sameh B. El Kafrawy and Mohamed A. Abouzeid. 2018. Antimicrobial Activities of Endophytic Fungi of Red Sea Aquatic Plant Avicennia marina. Egypt. J. Microbiol. Vol. 53, pp. 231 240 (2018)

Marcellano, J. P., Alyssa S. Collanto, Rolly G. Fuentes. 2017. Antibacterial Activity of Endophytic Fungi Isolated from the Bark of Cinnamomum mercadoi. Pharmacognosy Journal, Vol 9, Issue 3, May-Jun, 2017.

Munifatul I. 2007. Skreening Potensi Antibakteri pada Beberapa Spesies Rumput Laut terhadap Bakteri Patogen pada Udang Windu. Jurnal BIOMA 9(2): 62-67. ISSN 1410-8801.

Nirjanta Nameirakpam. 2012. Antimicrobial Properties Of Endophytic Kapang Isolated From Medicinal Plant Camellia Sinesis. International Journal Of Pharma and Bio Science 3 (3) : 420 427.

Noverita, Fitria, D. dan Sinaga, E. 2009. Isolasi dan Uji Aktivitas Antibakteri 
Jamur Endofit dari Daun dan Rimpang Zingiber ottensii Val. Jurnal Farmasi Indonesia. 4: 171-176.

Onifade, AK. 2007, Research trends : Bioactive metabolites of fungal origin.

Res. J. of Biol. Scie. 2 (1): 81-84.

Pelczar MJ, Chan ESC. 2008. Dasar-Dasar Mikrobiologi 2. Hadioetomo,

Penerjemah. Jakarta (ID): UI-Press.

Terjemahan dari: Elements of Microbiology. 99-156, 447-508.

Prihatiningtias, W. 2005. Senyawa Bioaktif Kapang Endofit Tumbuhan Akar Kuning (Fibraurea chloroleuca Miers) Sebagai Agensia Antimikroba. Tesis. Program Studi Bioteknologi, Sekolah Pascasarjana UGM.

Priya M. Somwanshi and M. G. Bodhankar. 2018. Antimicrobial Activity of Endopytic Penicillium sp. and Fusarium moniliforme against MDR Human Pathogens. Int.J.Curr.Microbiol.App.Sci (2015) 4(5): 358-361.

Radji, M. Peran Bioteknologi dan mikroba endofit Dalam pengembangan obat herbal. Ravikumar, S., S. Nazar, A. Nural Shiefa and S. Abideen : Antibacterial activity of traditional therapeutic coastal medicinal plants against some pathogens. J. Environ. Biol., 26, 383-386 (2005).

Rahmawaty. 2012. Potensi Aspergillus niger dan Penicillium spp. Sebagai Endosimbion Pelarut Fosfat Pada Akar Serealia. [Skripsi]. Bogor : Institut Pertanian Bogor.

Ramadhiani, A.R., Urip Harahap, Aminah Dalmunthe. 2018. Nephroprotective Activity of ETHANOL Extract Root Of Cogon Grass (Imperata Cylindrica L. (BEAUV.)) on Creatinine, Urea Levels, and Hematology Profile Against Gentamycin-Induced Renal Toxicity In Rats. Asian J Pharm Clin Res, Vol 11, Special issue 1, 2018.

Refdanita, Maksum R, Nurgani A, Endang P. 2004. Pola Kepekaan Kuman Terhadap Antibiotik di ruang intensif
Rumah Sakit Fatmawati Jakarta Tahun 2001-2002. Jakarta: Makara Kesehatan vol.8(2).

Rodriguez, R.J., J.F. White, A.E. Arnold and R.S Redman. 2008. Fungal endophytes: diversity and functional roles. http://www.newsphytologis.org.

Rosalina, R. Riska Surya Ningrum, Prima Agusti Lukis. 2018. Aktifitas Antibakteri Ekstrak Jamur Endofit Mangga Podang (Mangifera indica L.) Asal Kabupaten Kediri Jawa Timur. Majalah Ilmiah Biologi Biosfera : $A$ Scientific Journal DOI: 10.20884/1.mib.2018.35.3.757. Vol 35, No 3 September $2018: 139$ - 144.

Seniwaty, Raihanah, Ika Kusuma N., Dewi Umaningrum. 2009. Skrining Fitokimia Dari Alang-Alang (Imperata cylindrica L. Beauv) dan Lidah Ular (Hedyotis corymbosa L. Lamk). Sains dan Terapan Kimia, Vol. 3 No. 2 (Juli 2009), $124-133$.

Setyaningsih, I. 2008. Ekstraksi Senyawa Antibakteri dari Diatom Chaetoceros gracilis dengan Berbagai Metode. Jurnal Biologi Indonesia. 5(1) : p 23 - 33.

Strobel G, Daisy B. 2003. Bioprospecting for microbial endophytes and their natural products. Microb Mol Biol Rev: 491-502.

Sukriani Kursia, Rahmad Aksa, Maria Magdalena Nolo. 2018. Potensi Antibakteri Isolat Jamur Endofit dari Daun Kelor (Moringa oleifera Lam.). Pharmauho Volume 4, No. 1, April 2018, Hal. 30-33. Majalah Farmasi, Sains, dan Kesehatan ISSN 2442-9791

Syarmalina, W., Lely, \& Laupa, N. (2007). Uji sitotoksik hasil fermentasi kapang endo-fit buah mahkota dewa (Phaleria mac-rocarpa) terhadap sel MCF-7. Jurnal Ilmu Kefarmasian Indonesia 5(1), 23-24.Tan, RX and Zou, WX. (2001). Endophytes : a rich Source of Functional Metabolites. Nat Prod. Rep. $18: 448-459$. 
Tan. RX and Zou WX. 2001. Endophytes:

A Rich Source of Functional Metabolites. Nat. Prod. Rep.18:448-459.

Waluyo, Lud. 2010. Teknik \& Metode

Dasar dalam Mikrobiologi. Malang: Universitas Muhammadiyah Malang Press 